\title{
Melatonin deprival modifies follicular and corpus luteal growth dynamics in a sheep model
}

\author{
Maria Elena Manca, Maria Lucia Manunta, Antonio Spezzigu , Laura Torres-Rovira, \\ Antonio Gonzalez-Bulnes², Valeria Pasciu, Peter Piu, Giovanni G Leoni, Sara Succu, \\ Didier Chesneau ${ }^{3,4}$, Salvatore Naitana and Fiammetta Berlinguer
}

\begin{abstract}
Department of Veterinary Medicine, University of Sassari, Via Vienna 2, 07100 Sassari, Italy, ${ }^{1}$ Embryo Sardegna, Technology, Reproduction, and Fertility, 07034 Perfugas, Località Suiles (SS), Italy, ${ }^{2}$ Department of Animal Reproduction, INIA, Avda. Puerta de Hierro s/n, 28040 Madrid, Spain, ${ }^{3}$ Institut National de la Recherche Agronomique (INRA), UMR85, F-37380 Nouzilly, France and ${ }^{4}$ CNRS, UMR 7247, Université François Rabelais de Tours, F-37041 Tours, France
\end{abstract}

Correspondence should be addressed to F Berlinguer; Email: berling@uniss.it

\begin{abstract}
This study assessed the effect of melatonin deprival on ovarian status and function in sheep. Experimental procedures were carried out within two consecutive breeding seasons. Animals were divided into two groups: pinealectomised $(n=6)$ and sham-operated $(n=6)$. The completeness of the pineal gland removal was confirmed by the plasma concentration of melatonin. Ovarian status was monitored by ovarian ultrasonography for 1 year to study reproductive seasonality. Follicular and corpus luteal growth dynamics were assessed during an induced oestrous cycle. As the effects of melatonin on the ovary may also be mediated by its antioxidant properties, plasma Trolox equivalent antioxidant capacity (TEAC) was determined monthly for 1 year. Pinealectomy significantly extended the breeding season $(310 \pm 24.7$ vs $217.5 \pm 24.7$ days in controls; $P<0.05)$. Both pinealectomised and sham-operated ewes showed a well-defined wave-like pattern of follicle dynamics; however, melatonin deficiency caused fewer waves during the oestrous cycle (4.3 \pm 0.2 vs $5.2 \pm 0.2 ; P<0.05)$, because waves were 1 day longer when compared with the controls $(7.2 \pm 0.3$ vs $6.1 \pm 0.3 ; P<0.05)$. The mean area of the corpora lutea $\left(105.4 \pm 5.9\right.$ vs $\left.65.4 \pm 5.9 \mathrm{~mm}^{2} ; P<0.05\right)$ and plasma progesterone levels $(7.1 \pm 0.7 \mathrm{vs} 4.9 \pm 0.6 \mathrm{ng} / \mathrm{ml} ; P<0.05) \mathrm{were}$ significantly higher in sham-operated ewes compared with pinealectomised ewes. In addition, TEAC values were significantly lower in pinealectomised ewes compared with control ones. These data suggest that melatonin, besides exerting its well-known role in the synchronisation of seasonal reproductive fluctuations, influences the growth pattern of the follicles and the steroidogenic capacity of the corpus luteum.
\end{abstract}

\section{Free Italian abstract}

An Italian translation of this abstract is freely available at http://www.reproduction-online.org/content/147/6/885/suppl/DC1. Reproduction (2014) 147 885-895

\section{Introduction}

Seasonal breeders have developed mechanisms to restrict fertility to a particular time of the year. This ensures the birth of the offspring during the most favourable season, generally when the resources needed to support the requirements of lactation and postweaning growth of the offspring are most abundant. Domestication may have attenuated or suppressed some of the various physiological expressions of seasonality, but domesticated small ruminants have retained most of them.

Sheep, like the majority of seasonal breeders, use photoperiod as the main environmental cue to establish the time of year. Ewes have a breeding season characterised by a succession of 16-18-day long oestrous cycles, which usually start in late summer or at the beginning of autumn and end in late winter or at the very beginning of spring, in the northern hemisphere but varies according to breed and latitude (Ortavant et al. 1985). Thereafter, the anoestrous season takes place without behavioural or ovarian cyclicity. Ambient photoperiod is transduced by a photoneuroendocrine system composed of the retina, the suprachiasmatic nucleus (seat of the master circadian clock) and the pineal gland (Malpaux et al. 2001). The latter releases the hormone melatonin exclusively at night, so that the duration of secretion varies according to day length 
and provides an endocrine representation of photoperiod (Malpaux et al. 2001, Simonneaux \& Ribelayga 2003). Melatonin transmits day length information to the neuroendocrine-gonadal axis exerting indirect actions on the Kiss1/GPR54 system responsible for controlling reproduction via the neural axis by tuning circulating gonadotrophin and sex steroid levels (Revel et al. 2007).

As described above, it is generally accepted that melatonin exerts its primary reproductive action at the level of the brain and pituitary. However, the presence of high melatonin levels in follicular fluid (Brzezinski et al. 1987) and the presence of receptors in granulosa cells (Yie et al. 1995, Niles et al. 1999, Woo et al. 2001, Soares et al. 2003a, Wang et al. 2012, Barros et al. 2013) have suggested a role of melatonin on ovarian function. This hypothesis has been confirmed by recent studies reporting strong evidence for melatonin action on the ovary, such as modulation of ovarian steroidogenesis (mainly progesterone $\left(\mathrm{P}_{4}\right)$ production; Taketani et al. 2011) and contribution in the maintenance of a proper follicular structure and function (Soares et al. 2003a,b, Barros et al. 2013, Maganhin et al. 2013). In a previous study, we demonstrated that melatonin supplementation during the anoestrous period modifies the pattern of follicular waves by increasing the turnover of dominant follicles (Berlinguer et al. 2009).

The main role of melatonin within the follicle may be also to act as a free radical scavenger. The antioxidant properties of melatonin have been extensively studied (Reiter et al. 2013, Tamura et al. 2013). The scavenger activity of melatonin or of its metabolites may thus account for its beneficial effect on follicular and oocyte development (Tamura et al. 2008).

This study aimed to investigate the effect of melatonin deprival on follicular and corpus luteal growth dynamics in sheep. In addition, the effect of melatonin deprival on blood total antioxidant capacity was determined.

\section{Materials and methods}

\section{Chemicals}

All reagents and media were purchased from Sigma Chemical Co. unless otherwise specified.

\section{Animals and experimental design}

Approval was obtained from the Institutional Animal Care and Use Committee, and all procedures conformed to the National Institutes of Health Guidelines for the Care of Laboratory Animals. All the animals used were adult multiparous Sarda ewes from a uniform flock $(n=12 ; 2.5-5$ years old, body weight $39.5 \pm 7.7 \mathrm{~kg}$ ) housed outdoors with indoor access and fed with a live-weight maintenance ration following nutritional requirements recommended by NRC (2007) for an adult ewe of $40 \mathrm{~kg}$ body weight. This study was conducted at the experimental facilities of the Department of Veterinary
Medicine of the University of Sassari, Italy (latitude $40^{\circ} 43^{\prime} \mathrm{N}$ ). These facilities meet the requirements of the European Union for Scientific Procedure Establishments.

All animals received physical and neurological examinations, complete blood count, serum biochemical analysis and urine analysis. Animals considered unhealthy were excluded from the study. Ewes were randomly divided into two groups: i) pinealectomised ewes $(n=6)$ and ii) shampinealectomised ewes $(n=6)$.

Plasma melatonin concentration was determined in each animal before the surgery, and 60 days and 12 months after the surgery. One year after the surgery, ewes were enrolled in the study for the evaluation of the effects of melatonin deprival on ovarian status. The observational period was comprised within two consecutive natural breeding seasons (from late August 2010 to late December 2011) described for this breed at this latitude. To determine the effect of melatonin deprival on reproductive seasonality, ovarian status was determined weekly during a complete natural year (starting on August 22) by transrectal ultrasonography. The presence of ovulation, and thus of oestrous cyclicity, was confirmed by the visualisation of corpora lutea. During this period, jugular blood samples were withdrawn every 30 days to evaluate total antioxidant capacity throughout a complete natural year in pinealectomised and sham-operated ewes.

At the end of the observation period (December), follicular and corpus luteal growth dynamics were monitored during an induced oestrous cycle in pinealectomised and sham-operated ewes. Ovulation was synchronised in all the ewes with two doses of $125 \mu \mathrm{g}$ prostaglandin analogue (cloprostenol, Estrumate, Essex Animal Health, Friesoythe, Germany) given 10 days apart. Corpora lutea and follicular development were assessed by daily transrectal ultrasonography performed from the day of oestrus detection with vasectomised rams until the next ovulation. Coincidentally, luteal cell function was evaluated daily by determining plasma $\mathrm{P}_{4}$ concentrations from jugular blood samples.

\section{Surgical procedure}

Pre-medication, induction, maintenance of anaesthesia, analgesic treatment and intraoperative monitoring

The ewes were kept off feed $24 \mathrm{~h}$ prior to surgery but had free access to water for up to 3-4 h prior to surgery. Ewes received $2.0 \mathrm{mg} / \mathrm{kg}$ i.v. ketoprofen (Vet-Ketofen 1\%, Merial, Assago, Italy), $0.4 \mathrm{mg} / \mathrm{kg}$ i.v. diazepam (Diazepam 0.5\%, Intervet $\mathrm{GmbH}$, Unterschleisssheim, Germany) and $6 \mu \mathrm{g} / \mathrm{kg}$ i.v. fentanyl (Fentanest, Actavis, Nerviano, Italy). The scalp and the subcutaneous tissue were infiltrated with $10 \mathrm{ml}$ mepivacaine 2\% (Mepibil, Hospira, Naples, Italy). For induction, sheep received $8 \mathrm{mg} / \mathrm{kg}$ thiopental sodium i.v. (Pentothal; Intervet $\mathrm{GmbH}$ ) followed by orotracheal intubation.

Ewes were maintained with sevoflurane (Sevoflo; Abbott Laboratories) in oxygen $\left(\mathrm{O}_{2}\right)$ /air through a small animal circle system (Fabius GS, Dräger, Lúbeck, Germany). Animals were maintained in mechanical ventilation and the ventilator was adjusted to maintain the end tidal $\mathrm{CO}_{2}$ between 28 and $32 \mathrm{mmHg}$ (moderate hyperventilation). 
Crystalloid solution ( $\mathrm{NaCl}$ 0.9\%; Acme, Cavriago, Italy) was infused at a rate of $5-10 \mathrm{ml} / \mathrm{kg}$ per $\mathrm{h}$ to support circulating blood volume. After the craniectomy, $1 \mathrm{ml}$ of $2 \%$ mepivacaine was dropped over the dura $1 \mathrm{~min}$ before its incision. At the end of the surgery, a bolus of i.v. buprenorphine $(0.02 \mathrm{mg} / \mathrm{kg}$; Temgesic, Schering-Plough S.p.A., Segrate, Italy) was administered to ensure an adequate post-operative analgesia and this procedure was repeated after $4 \mathrm{~h}$. Just before the extubation i.v. lidocaine $(1 \mathrm{mg} / \mathrm{kg}$ in bolus; Lidocaina $2 \%$, Fort Dodge, Aprilia, Italy) was administered to avoid an increase in intracranial pressure.

\section{Pinealectomy}

Briefly, animals were placed in sternal recumbency with the head elevated no more than $30^{\circ}$ above cardiac level with the tip of the nose tilted downwards and secured in a craniotomy head stand. A dorsal midline skin incision of $\sim 5-7 \mathrm{~cm}$ in length was made beginning from the proximal attachment of the ligamentum nuchae with rostral direction. The subcutaneous fascia and the thin cutaneous muscles of the head (m. occipitalis and $\mathrm{m}$. frontalis) were divided medially. The underlying muscles cervicoscapular and parietoauricularis were medially incised, divided, elevated and retracted with Gelpi self-retractor to expose the underlying skull.

Craniectomy was then performed using an electrical drill with round burs. Pinealectomy was performed according to the procedure described by Dempsey et al. (1982). On opening the dura mater, the left parietooccipital cortex, the proximal portion of the tentorium cerebelli and, shielded by the edge of the bone opening, the dorsal sinus were exposed. The brain was bathed almost continuously in warm sterile saline. With a padded retractor inserted into the transversal cerebral fissure, the parietooccipital lobe was gently moved in rostral and lateral direction, thus allowing exposure of the deepest portion of the tentorium cerebelli. The vault of the quadrigeminal cistern was opened with a dissector and the cerebrospinal fluid was drained. Inserting the second spatula, the rostral colliculi were reached rostrally and dorsally to visualise the pineal gland. With the help of a dissector, the gland was delicately freed from the little vessels and nerves that surround it and, ventrally, from the internal and basal cerebral veins. The epiphysis was grasped and removed with forceps. Synthetic graft (Graftygen, Tecnoss s.r.I., Torino, Italy) was sutured over the dural and the skull defects. The muscles were apposed on midline and the subcutaneous tissue and the skin were apposed routinely. The animals were given daily antibiotic (amoxicillin + clavulanic acid, $20 \mathrm{mg} / \mathrm{kg}$ per day for 10 days i.m.) and anti-inflammatory therapy for 5 days. The same procedure was performed on the animals in the sham-pinealectomised group, but the pineal gland was left in situ.

\section{Morphometric evaluation of follicular and corpus luteal growth dynamics}

Ovaries were examined by transrectal ultrasonography using a real-time B-mode scanner (Aloka SSD 500, Aloka Co., Tokyo, Japan) fitted to a $7.5 \mathrm{MHz}$ linear array probe. Scanning was performed as described previously (Gonzalez-Bulnes et al.
2010). In brief, after introducing a hydrosoluble contact gel into the rectum, the transducer was introduced perpendicular to the abdomen wall. When the urinary bladder was surpassed and the uterine horns were located, the probe was rotated laterally $90^{\circ}$ clockwise and $180^{\circ}$ anticlockwise to observe both ovaries and their structures.

Each ovary was scanned several times from different angles in order to ensure that all follicles $\geq 2 \mathrm{~mm}$ (during the follicular phase) and corpora lutea (during the luteal phase) were seen. The largest diameter of each follicle and the area of the corpora lutea were measured using the electronic callipers of the ultrasound machine. The position of the largest follicles was recorded on a diagram of each ovary. In those corpora lutea bearing a cavity, its area was calculated and subtracted for obtaining the correct measurement of the area occupied by the luteal tissue.

\section{Hormone assay}

For the evaluation of plasma melatonin concentrations, two blood samples were taken from the jugular vein using vacuum blood evacuation tubes containing EDTA (Vacutainer Systems Europe, Becton Dickinson, Meylan Cedex, France). The samples were withdrawn in the afternoon at $1200 \mathrm{~h}$ and at night at $2400 \mathrm{~h}$ in the dark, immediately centrifuged and preserved at $-80{ }^{\circ} \mathrm{C}$ until assayed. Melatonin concentration was determined as described previously (Zarazaga et al. 2010). In short, melatonin was assayed by a direct RIA method with 2-[125I] iodomelatonin as a tracer (Vakkuri et al. 1984) and a previously described anti-melatonin antiserum (Tillet et al. 1986) (melatonin Fluka-63610). This direct assay, originally described by Fraser et al. (1983), was performed according to the modifications of Webley et al. (1985) and Ravault et al. (1989). Briefly, $100 \mu \mathrm{l}$ rabbit anti-melatonin antiserum (final dilution: $1 / 400000)$ and $300 \mu \mathrm{l} 2$-[125I]iodomelatonin (15 000 c.p.m./tube) were added to $100 \mu$ l assay buffer (tricine) or undiluted plasma. After $16-18 \mathrm{~h}$ of incubation at $4{ }^{\circ} \mathrm{C}$, the antigen-antibody complexes formed were precipitated by addition of $1 \mathrm{ml}$ sheep anti-rabbit antiserum (INRA). After $1 \mathrm{~h}$ of incubation, the samples were centrifuged ( $2800 \boldsymbol{g}$ for $30 \mathrm{~min}$ at $4{ }^{\circ} \mathrm{C}$ ), then the supernatant was discarded and the pellet counted on a Gamma counter. A standard curve consisting of $4-1000 \mathrm{pg} / \mathrm{ml}$ melatonin in pinealectomised sheep plasma was prepared. The value of coefficient of variation (CV) was estimated by assaying three plasma pools (low, medium and high concentrations) in duplicate for every 50 unknown samples. All samples were analysed in the same assay and the intra-assay $\mathrm{CV}$ value was $12.8 \%$.

The luteal cell functionality was assessed by determining plasma concentrations of $\mathrm{P}_{4}$ in samples obtained, coincidentally with ultrasound scanning, using vacuum blood evacuation tubes containing lithium heparin (Vacutainer Systems Europe, Becton Dickinson). Immediately after recovery, blood samples were centrifuged at $1500 \mathrm{~g}$ for $10 \mathrm{~min}$, and plasma was removed and stored at $-20^{\circ} \mathrm{C}$ until assayed. $\mathrm{P}_{4}$ levels were measured in duplicate using a commercial ELISA Kit (DRG Instruments $\mathrm{GmbH}$, Marburg, Germany), which is a solidphase ELISA, based on the principle of competitive binding. The microtiter wells were coated with a polyclonal antibody 
directed towards an antigenic site on the $\mathrm{P}_{4}$ molecule. Endogenous $\mathrm{P}_{4}$ of a sample competes with a $\mathrm{P}_{4}-\mathrm{HRP}$ conjugate for binding to the coated antibody. After incubation, the unbound conjugate is washed off. The amount of bound enzyme conjugate is visualised by the addition of the substrate solution (3,3',5,5'-tetramethylbenzidine) and incubation that leads to the development of a blue colour. The substrate reaction is stopped by the addition of sulphuric acid. The colour intensity is measured photometrically at $450 \mathrm{~nm}$ and is inversely proportional to the $\mathrm{P}_{4}$ concentration in the sample. All kit reagents, controls and stored samples to be analysed were brought to room temperature $\left(25^{\circ} \mathrm{C}\right)$ at the beginning of the test. All assays were performed using the Personal Lab Adaltis (Adaltis srl, Rome, Italy), which is a tool that performs automated ELISA protocols. The analytical sensitivity was $0.045 \mathrm{ng} / \mathrm{ml}$ and the intra- and interassay CV values were $<10 \%$.

\section{Determination of Trolox equivalent antioxidant capacity in plasma}

Samples of blood plasma (EDTA) were processed rapidly and kept frozen at $-80{ }^{\circ} \mathrm{C}$ until assayed. Plasma Trolox equivalent antioxidant capacity (TEAC) was determined using the method described by Re et al. (1999) and modified by Lewinska et al. (2007). Briefly, a fresh solution was prepared by dissolving $19.5 \mathrm{mg} \mathrm{2,2}$ '-azinobis(3-ethylbenzthiazoline-6-sulphonic acid (ABTS)) and $3.3 \mathrm{mg}$ potassium persulphate in $7 \mathrm{ml}$ of $0.1 \mathrm{~mol} / \mathrm{l}$ phosphate buffer, $\mathrm{pH}$ 7.4. This solution was stored in the dark for $12 \mathrm{~h}$ for completion of the reaction. ABTS + solution was diluted (usually $\sim 1: 80$ ) in $0.1 \mathrm{~mol} / \mathrm{l}$ phosphate buffer, $\mathrm{pH} 7.4$, to give an absorbance reading of 1.0 at $734 \mathrm{~nm}$ and mixed thoroughly. The absorbance of the mixture was measured twice in a spectrophotometer (Thermo Elecron Corporation Genesys 10 u.v., Madison, WI, USA), at $734 \mathrm{~nm}$ for 3 min after mixing a sample with the ABTS + solution. The extent of ABTS + bleaching (decrease in absorbance, corrected for a small decrease in absorbance of ABTS + solution alone) is proportional to the activity of antioxidants in a given sample. The antioxidant capacity was expressed as TEAC, that is, the concentration (amount) of Trolox producing the same effect as the sample studied. Calculations were made on the basis of standard curves obtained for a Trolox solution (5-20 $\mu$ M Trolox).

\section{Statistical analyses}

To analyse differences in growth patterns, data for the number of follicles and functionality of corpora lutea were normalised with respect to the day in which ovulation was detected. First, ultrasonographic data during the induced oestrous cycle were summarised to characterise patterns of ovarian follicular development. All follicles detected by ultrasonography were classified by their largest diameter and, thereafter, were grouped as total $(\geq 2 \mathrm{~mm})$, large $(\geq 4 \mathrm{~mm})$ or small follicles $(<4 \mathrm{~mm})$. Secondly, ultrasonographic and plasma hormonal data during luteal phase were summarised to characterise patterns of growth dynamics and functionality of corpora lutea. Data on individual growth of dominant follicles were used to characterise follicular waves on the basis of: i) wave onset (emergence), the day on which follicles were first detected at $3 \mathrm{~mm}$; ii) growth phase (length), the time taken by a single follicle to grow from $3 \mathrm{~mm}$ to its maximum diameter; iii) regression phase, the time taken by a single follicle to regress from its maximum size until the day on which it reached its smallest size; iv) wave end, the day when the dominant follicle ended its regressing phase and $\mathrm{v}$ ) wave duration (total length), the time taken by a single follicle to grow from $3 \mathrm{~mm}$ to its maximum diameter and to completely regress to its minimum size. Effects of day and wave of follicular development on individual characteristics of dominant follicle throughout the study were assessed by ANOVA. Effects of melatonin deprival on the time length of the reproductive season, number and size of follicles, number of ovulations per cycle, size of corpora lutea, hormone concentrations and TEAC values were analysed by a split-plot ANOVA, followed by a Kruskal-Wallis test, when Levene's test showed nonhomogeneous variables. Duncan's multiple range tests were used for significant interactions.

Statistical analysis was performed using the statistical software program Statgraphics Centurion XV (version 15.2.06 for Windows; StatPoint, Inc., Herndon, VA, USA) and a probability of $P \geq 0.05$ was considered to be the minimum level of significance. All results were expressed as the mean \pm s.E.M.

\section{Results}

Determination of melatonin plasma levels confirmed the surgical removal of the pineal gland in pinealectomised ewes (Fig. 1). Melatonin concentration during the day did not differ in the two groups, being $<4 \mathrm{pg} / \mathrm{ml}$. After the surgery, the night values did not rise in pinealectomised ewes and remained significantly lower than that in sham-operated ewes $(P<0.01)$.

Reproductive seasonality was affected by melatonin deprival. Pinealectomised ewes had a longer reproductive season when compared with sham-operated ewes

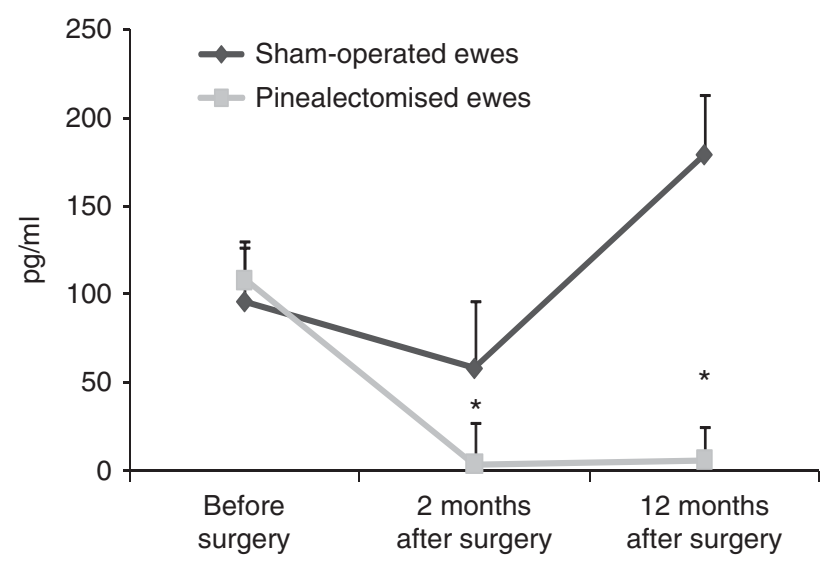

Figure 1 Night values of melatonin (blood sampling was performed at $2400 \mathrm{~h})$ in sham-operated $(n=6)$ and pinealectomised ewes $(n=6)$ before and after the surgery ( 2 and 12 months). *Significant difference between sham-operated and pinealectomised ewes (ANOVA, $P<0.05$ ). 

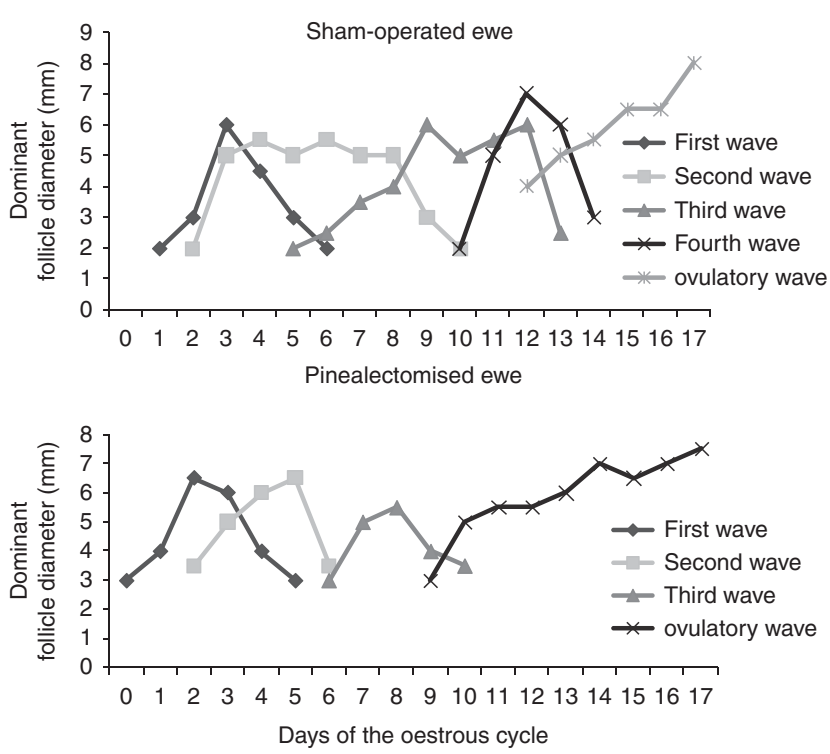

Figure 2 Example of wave-like pattern of follicle dynamics in shamoperated and pinealectomised ewes during an induced oestrous cycle in the breeding season.

( $310 \pm 24.7$ vs $217.5 \pm 24.7$ days respectively; $P<0.05)$. Two pinealectomised ewes cycled year round.

The time length of the induced oestrous cycle $(17 \pm 1.6$ vs $18.2 \pm 1.4$ days in sham-operated and pinealectomised ewes respectively) and the ovulation rate $(1.4 \pm 0.2$ vs $1.1 \pm 0.2$ in sham-operated and pinealectomised ewes respectively) did not differ between the two experimental groups.

The ultrasonographic study indicated that both pinealectomised and sham-operated ewes showed a well-defined wave-like pattern of follicle dynamics (Fig. 2); however, there were some significant differences between groups in the characteristics of the follicular waves (Table 1).

Pinealectomy resulted in fewer waves during the oestrous cycle $(4.3 \pm 0.2$ vs $5.2 \pm 0.2 ; P<0.05)$, because waves were 1 day longer when compared with the controls $(P<0.05)$. Analysing one by one the different follicular waves through the oestrous cycles, it was observed that the longest waves in pinealectomised ewes were the third ( $8.2 \pm 0.8$ days) and the fourth $(8.3 \pm$ 0.8 days; Fig. 3 ) waves. In particular, they lasted longer when compared with both the ovulatory wave (5.2 \pm 0.5 days; $P<0.05)$ and the respective follicular waves in sham-operated ewes (third wave, $6 \pm 0.9$ days and fourth wave, $5.8 \pm 0.6$ days; $P<0.05)$. In addition, the regression phase of the first follicular wave lasted longer in pinealectomised ewes compared with control ones ( $2 \pm 0.2$ vs $1.1 \pm 0.2$ respectively; $P<0.05$ ). In contrast to pinealectomised ewes, where no differences emerged among the length of the dominant follicle growth phase through the oestrous cycle, in sham-operated ewes ovulatory follicles took longer ( $5.5 \pm 0.4$ days) to reach their maximum diameter when compared with the other follicles which developed during the luteal phase (first wave, $3.3 \pm 0.5$ days; second wave, $4.3 \pm 0.5$; third wave, $3.6 \pm 0.5$ and fourth wave, $3.5 \pm 0.5 ; P<0.05$ ). No differences were recorded in ovulatory wave characteristics between the two experimental groups.

The number of small $(<4 \mathrm{~mm}$ in diameter), large $(\geq 4 \mathrm{~mm})$ and total follicles $(\geq 2 \mathrm{~mm})$ varies across the oestrous cycle in both groups (Fig. 4). In particular, in sham-operated ewes, the number of small, large and total follicles increased during the luteal phase, peaked approximately within days 10 and 15 of the oestrous cycle and then dropped again in the follicular phase $(P<0.05)$. In pinealectomised ewes, the pattern of follicle development was not homogeneous among the different follicle categories. Small follicles peaked in the very first days of the luteal phase, then rose again at the end of the luteal phase (days 9-15) and in the first days of the follicular phase $(P<0.01)$. In the same way, no precise pattern of follicle development could be depicted for large follicles. The same pattern was followed approximately by the number of total follicles. In addition, the mean number of follicles belonging to the different categories differed between the two experimental groups. The number of small follicles was higher in pinealectomised ewes compared with shamoperated ones $(13.5 \pm 0.3$ vs $12.2 \pm 0.3 ; P<0.05)$. Conversely, the number of large follicles was higher in sham-operated ewes compared with pinealectomised ones $(2.7 \pm 0.1$ vs $2.3 \pm 0.1 ; P<0.05)$. No difference was recorded in the mean number of total follicles.

The mean area of the corpora lutea recorded by ultrasonography was significantly smaller in pinealectomised ewes compared with sham-operated ones (65.4 \pm 5.9 vs $\left.105.4 \pm 5.9 \mathrm{~mm}^{2} ; P<0.0001\right)$. These differences were confirmed by the analysis of plasma $\mathrm{P}_{4}$ level (Fig. 5), whose mean values were lower in pinealectomised ewes compared with sham-operated ones $(4.9 \pm 0.6$ vs $7.1 \pm 0.7 \mathrm{ng} / \mathrm{ml} ; P<0.05)$.

TEAC values were significantly lower in pinealectomised ewes compared with control ones $(P<0.01$; Fig. 6A). No difference was observed in the two

Table 1 Characteristics of the follicular waves in pinealectomised $(n=6)$ and sham-operated ewes $(n=6)$ during an induced oestrous cycle in the breeding season.

\begin{tabular}{lcc}
\hline & $\begin{array}{c}\text { Sham-operated } \\
\text { ewes } \\
\text { (mean } \pm \text { s.E.M.) }\end{array}$ & $\begin{array}{c}\text { Pinealectomised } \\
\text { ewes } \\
\text { (mean } \pm \text { s.E.M.) }\end{array}$ \\
\hline Number of follicular waves & $5.2 \pm 0.2^{\mathrm{a}}$ & $4.3 \pm 0.2^{\mathrm{b}}$ \\
Follicular wavelength (days) & $6.1 \pm 0.3^{\mathrm{a}}$ & $7.2 \pm 0.3^{\mathrm{b}}$ \\
$\begin{array}{l}\text { Maximum diameter reached } \\
\text { by DF (mm) }\end{array}$ & $5.8 \pm 0.1$ & $5.9 \pm 0.1$ \\
DF growth rates (mm/day) & $0.74 \pm 0.05$ & $0.69 \pm 0.05$ \\
DF regression rates (mm/day) & $1.4 \pm 0.1$ & $1.4 \pm 0.1$ \\
DF growth phase (days) & $3.9 \pm 0.2$ & $4.5 \pm 0.2$ \\
DF regression phase (days) & $1.8 \pm 0.2$ & $2.4 \pm 0.2$ \\
\hline
\end{tabular}

In the same row, different superscripts indicate statistical difference (ANOVA $\mathrm{a} \neq \mathrm{b}, P<0.05)$. DF, dominant follicles. 

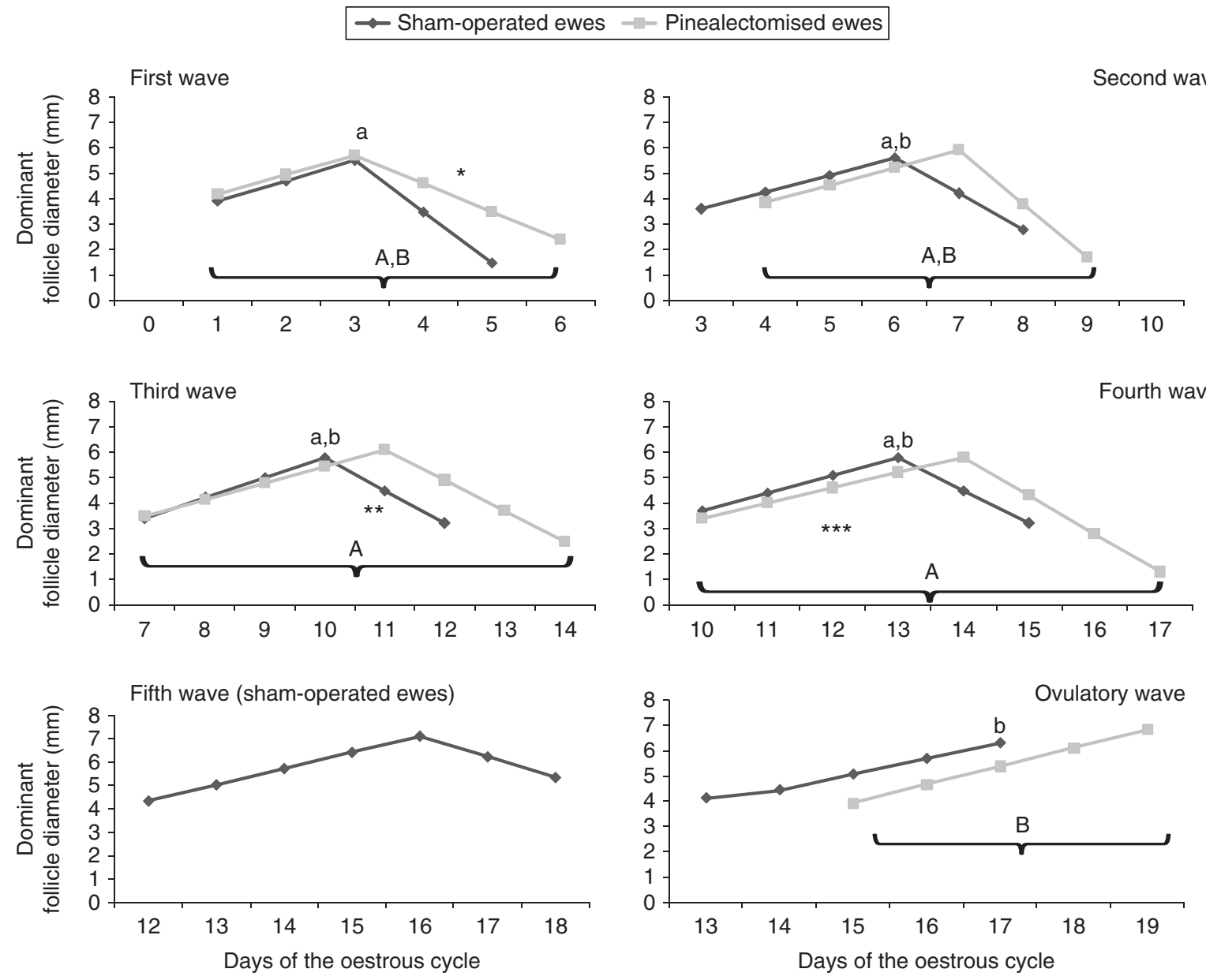

Figure 3 Differences in the characteristics of the follicular waves in sham-operated $(n=6)$ and pinealectomised ewes $(n=6)$ during an induced oestrous cycle in the breeding season. *Difference in regression rates between experimental groups (ANOVA, $P<0.01$ ). ${ }^{* *}$ Difference in wavelength between experimental groups (ANOVA, $P<0.05$ ). ${ }^{* * *}$ Difference in both wavelength and growth rates between experimental groups (ANOVA, $P<0.05)$. Different letters indicate differences among wave characteristics in the same group: lower case letters in sham-operated ewes indicate differences in maximum diameter of follicles and upper case letters in pinealectomised group indicate differences in wavelength (ANOVA, $P<0.05$ ).

experimental groups when data were analysed on a monthly basis (Fig. 6B).

\section{Discussion}

Three main conclusions can be drawn from our study. First, we are reporting for the first time that melatonin deprival affects follicular wave growth pattern during the oestrous cycle. Secondly, it also affects corpus luteal growth and function, in terms of $\mathrm{P}_{4}$ production. Thirdly, we are confirming previous studies reporting that pinealectomy alters reproductive seasonality in seasonal breeders (Dardente 2012).

Melatonin plays a deterministic role in the regulation of seasonal reproduction in mammals. Classical studies in sheep, and other mammalian species expressing circannual rhythms, indicated that elimination of the circadian secretion of melatonin by removal of the

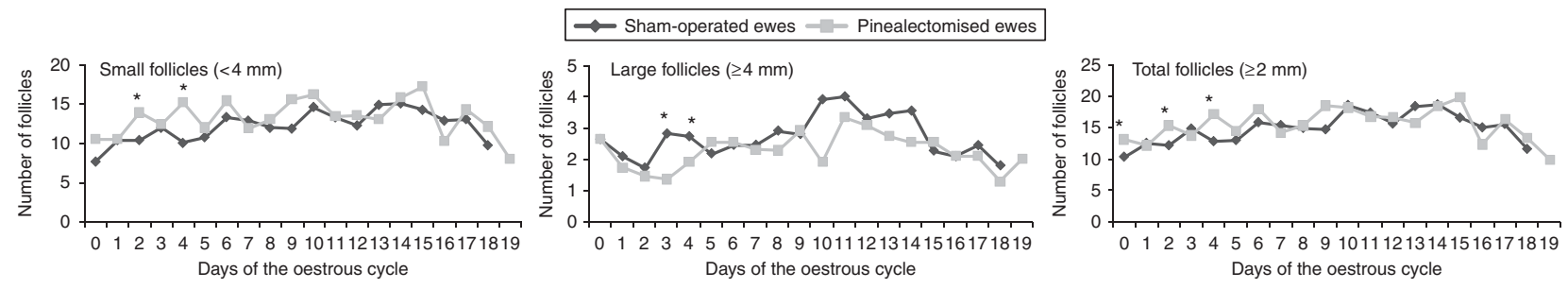

Figure 4 Number of small ( $<4 \mathrm{~mm}$ in diameter), large $(\geq 4 \mathrm{~mm})$ and total follicles $(\geq 2 \mathrm{~mm})$ in sham-operated $(n=6)$ and pinealectomised ewes $(n=6)$ during an induced oestrous cycle in the breeding season. *Significant difference between sham-operated and pinealectomised ewes (ANOVA, $P<0.05)$. 

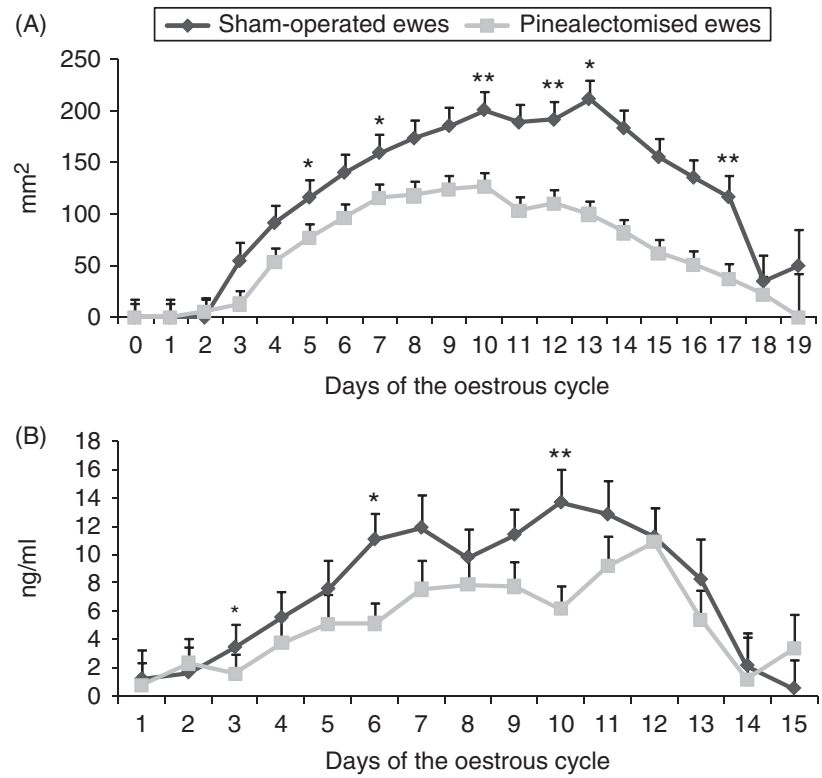

Figure 5 Mean area of corpora lutea (A) and plasma progesterone levels (B) in sham-operated $(n=6)$ and pinealectomised ewes $(n=6)$ during an induced oestrous cycle in the breeding season. Day 0, oestrus onset. * Significant difference between sham-operated and pinealectomised ewes (ANOVA, $P<0.05)$. ${ }^{* *}$ indicates values which tended to be significantly different between sham-operated and pinealectomised ewes (ANOVA, $P<0.056$ )

pineal gland disrupts photoperiodic responsiveness and causes circannual rhythms to free-run (Herbert et al. 1978, Zucker 1985, Woodfill et al. 1994). It has been described that pinealectomy abolishes seasonal responses, while melatonin administration restores them (Reiter et al. 1980, Woodfill et al. 1994, Arendt 1998). This study demonstrated a significant extension of the reproductive season in pinealectomised ewes, with two ewes cycling all year round.

At all stages of the breeding season and throughout seasonal anoestrus, the growth of antral ovarian follicles exhibits a distinct wave-like pattern in ewes (Bartlewski et al. 1998, Evans et al. 2000). During the breeding season, in both prolific and non-prolific breeds, there are typically three or four waves of follicle emergence per interovulatory interval (for review, see Bartlewski et al. (2011)). This pattern of antral follicular development is closely associated with periodic elevations in serum concentrations of follicle-stimulating hormone ( $\mathrm{FSH}$ ); peaks of transient increases in daily $\mathrm{FSH}$ concentrations occur just prior to follicle wave emergence (Bartlewski et al. 2000).

In this study, pinealectomy did not modify the pattern of follicular development, as pinealectomised ewes showed a well-defined wave-like pattern of follicular dynamics. On the other hand, follicular development was altered by melatonin deprival, as evidenced by the lower number of follicular waves and by their longer length in pinealectomised ewes. This result confirms previous findings in goats that melatonin treatment during the anoestrous season increases the turnover of dominant follicles by reducing their period of emergence, thus shortening the time length of the follicular waves (Berlinguer et al. 2009). Melatonin has been proposed to regulate the pulsatile secretion of gonadotropin-releasing hormone from the hypothalamus, thereby influencing $\mathrm{FSH} /$ luteinising hormone (LH) secretion (Bronson 1995) and favouring follicular development. Recent data suggest that, in seasonal breeders, melatonin could act on the KiSS1 cells to modulate reproductive activity (for review, see Revel et al. (2007)). In the ewe, which is a short-day breeder and so responds to a long melatonin secretion period, there is evidence that the pattern of melatonin secretion governs KISS1 mRNA expression in the arcuate nucleus (Smith 2012). Considering that kisspeptin potently elicits LH/FSH secretion (Thompson et al. 2004, Messager et al. 2005), the activation of this endocrine pathway may create a more suitable hormonal milieu for follicle growth, and this may explain the slower rate of follicular development in pinealectomised ewes.

It should be pointed out that gonadotrophins work in concert with locally produced growth factors, such as the insulin-like growth factors (IGFs), to promote and regulate follicular development. IGFs are mitogenic and antiapoptotic peptides produced by granulosa and theca cells during follicular development (Poretsky et al. 1999). These factors stimulate DNA synthesis and oestradiol and $\mathrm{P}_{4}$ secretion by human granulosa and granulosa-luteal cells (Poretsky et al. 1999). It has been demonstrated that melatonin stimulates IGF1 production
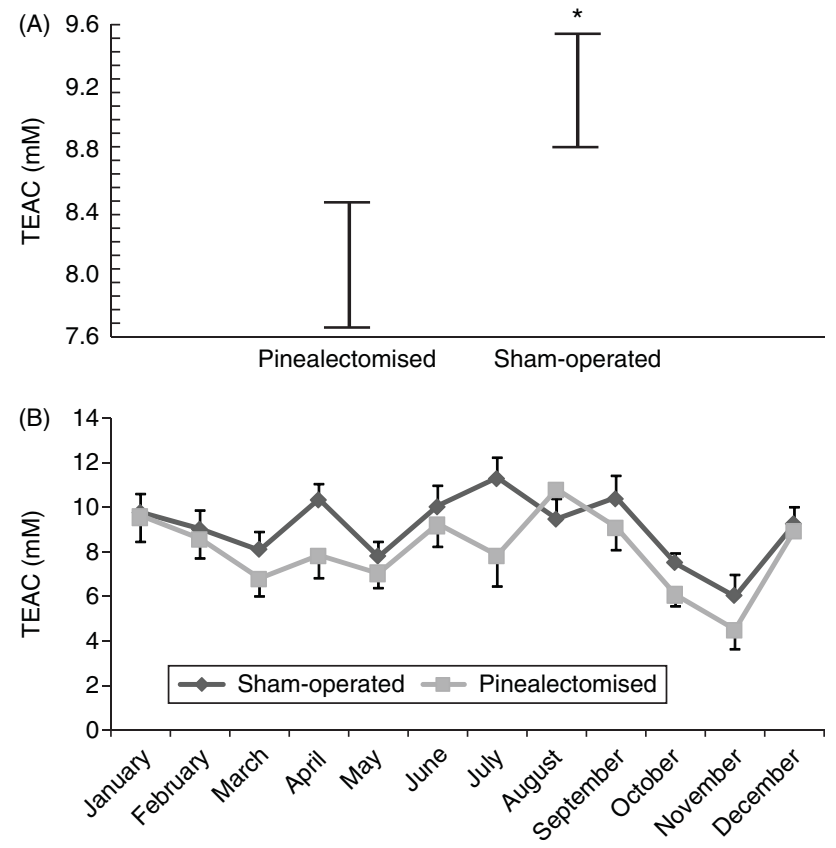

Figure 6 Trolox equivalent antioxidant capacity (TEAC) values of blood from pinealectomised $(n=6)$ and sham-operated ewes $(n=6)$ : (A) mean values and (B) monthly values. *Significant difference between pinealectomised and sham-operated ewes (ANOVA, $P<0.01$ ). 
by cultured human granulosa cells (Schaeffer \& Sirotkin 1997). Thus, a disturbance in IGF1 action may also have contributed to the slower rate of follicular development in pinealectomised ewes.

In this study, the alteration in follicular growth pattern observed in pinealectomised ewes was not accompanied by alterations in the process of ovulation, as the ovulation rate did not differ between pinealectomised and sham-operated ewes. In rats, pinealectomy resulted in the absence of ovulation (Maganhin et al. 2013), while in other species no changes in ovulation rates were observed after the surgical removal of the pineal gland (wolf, Grubaugh et al. (1982) and pony mare, Asa et al. (1987)). A previous study reported that pinealectomised ewes can have a normal pregnancy and deliver a healthy newborn (Kennaway et al. 1985). More recent studies suggest that melatonin have a role in the process of ovulation (Tamura et al. 2009), considering the presence of both types of membrane melatonin receptors in granulosa cells and that melatonin can up-regulate LHCGR mRNA (Woo et al. 2001). The LH is essential for the initiation of luteinisation. In addition, elevated melatonin in preovulatory follicles is likely to protect granulosa cells and the oocyte from free radicals that are induced during ovulation (Tamura et al. 2009). Thus, further studies are needed to investigate the exact role of melatonin in the ovulatory process.

Poor follicular development may result in production of an inadequate corpus luteum (Vasconcelos et al. 2001, Jimenez-Krassel et al. 2009). As a matter of fact, ovulation in pinealectomised ewes led to the formation of smaller corpora lutea, which produced less $\mathrm{P}_{4}$ when compared with sham-operated ewes. The poor corpus luteum function may also be explained by the indirect and direct actions of melatonin on luteal cells. As described above, melatonin stimulates $\mathrm{LH} / \mathrm{FSH}$ secretion. $\mathrm{LH}$ regulates a variety of ovarian functions, although its main effect may be to stimulate $\mathrm{P}_{4}$ secretion by the corpus luteum. In fact, LH strongly stimulates $\mathrm{P}_{4}$ production by cultured bovine luteal cells (Juengel \& Niswender 1999) and plays some luteoprotective roles by increasing luteal cell viability (Kawaguchi et al. 2013).

Melatonin also exerts a direct action on the corpus luteum. Melatonin-binding sites have been detected in granulosa-luteal cells in humans (Yie et al. 1995, Woo et al. 2001) and in cattle (Wang et al. 2012). Previous studies demonstrated that melatonin significantly increased $\mathrm{P}_{4}$ production in in vitro-cultured human and bovine granulosa cells (Webley \& Luck 1986). Similarly, this effect has been described in many other species, including rats and sheep (Durotoye et al. 1997, Adriaens et al. 2006). On the contrary, some reports showed no effects or negative effects of melatonin on $\mathrm{P}_{4}$ production in the growing and luteinised granulosa cells (Sirotkin 1994, Murayama et al. 1997, Schaeffer \& Sirotkin 1997, Bodis et al. 2001, Nakamura et al. 2003). The interpretation of studies on the in vitro effects of melatonin on steroidogenesis is complicated and seems to depend on cell types (theca or granulosa cells), duration of treatment (acute or long-term response), experimental model (cell culture or follicle culture), species, dose and different culture media (Tamura et al. 2009). In vivo studies showed that melatonin stimulates $\mathrm{P}_{4}$ production both in sheep (Durotoye et al. 1997, Vázquez et al. 2010) and in rats (Dair et al. 2008, Romeu et al. 2011, Maganhin et al. 2013). These findings are confirmed by results of this study, showing that both $\mathrm{P}_{4}$ production and corpus luteum growth were impaired in pinealectomised ewes. This result may be explained taking into account that melatonin remarkably increases mRNA expression of the LHCGR (but not FSHR) in human granulosa-luteal cells (Woo et al. 2001).

In addition, thanks to its well-known antioxidant properties (Tamura et al. 2013), melatonin, together with several of its derivates, also functions as a direct free radical scavenger to reduce oxidative stress at the level of the ovary; this beneficial action is carried out without an interaction with a receptor. Additional antioxidant functions of melatonin are achieved when the indole stimulates enzymes (superoxide dismutase, glutathione peroxidase and catalase), which metabolise free radicals to less toxic products in thecal cells, granulosa cells and in the follicular fluid (Reiter et al. 2013). Melatonin reduces free radical damage and maintains the follicle in an optimally functional state via these actions (Reiter et al. 2013). This study revealed a lower total antioxidant capacity in the plasma of pinealectomised ewes when compared with sham-operated ones and confirmed previous studies reporting a direct relationship between circulating melatonin levels and total antioxidant capacity in blood (Benot et al. 1998, 1999, Reiter et al. 2005). This finding may also explain the impaired follicular and corpora luteal function found in pinealectomised ewes.

In particular, melatonin antioxidant action has a key role at the moment of ovulation and corpus luteum formation (Tamura et al. 2013). Melatonin is likely to protect the corpus luteum from reactive oxygen species (ROS) and has an important role in maintaining its function. ROS have been reported to inhibit $\mathrm{P}_{4}$ production by luteal cells through the inhibition of steroidogenic enzymes (Behrman et al. 2001) and intracellular carrier proteins involving transport of cholesterol to mitochondria (Behrman \& Aten 1991). ROS also disrupt the plasma membrane of luteal cells because of lipid peroxidation and, as a consequence, membrane damage is often seen in the regressing corpus luteum (Gatzuli et al. 1991, Vega et al. 1995). In this way, melatonin prevented apoptosis in in vitro-cultured bovine granulosa cells (Wang et al. 2012).

Pineal-derived melatonin is not a conventional hormone, as it has both receptor-mediated and receptor-independent actions and, thanks to its highly lipophilic nature, virtually all cells are its targets whether 
or not they possess receptors for the indolamine. In addition, recent findings strongly suggest that also its metabolites exert a biological action (for review, see Hardeland et al. (2009)). Disturbances of the melatonin rhythm, which are a reflection of generalised chronodisruption, have a variety of potential consequences (Korkmaz et al. 2009). It has been long known that pinealectomy causes hypertension (Simko et al. 2013) and decreases daily secretion of insulin stimulated by glucose intake (Lima et al. 1998). An alteration in the blood flow of the corpus luteum has been associated with smaller size and low plasma $\mathrm{P}_{4}$ concentrations (Lüttgenau et al. 2011). A disturbance in carbohydrate homeostasis may alter the development of both the follicle and the corpus luteum (Robinson et al. 2006). Thus, both the metabolic and the cardiovascular actions of melatonin could have contributed to the slower follicular development and to development of smaller corpora lutea observed in pinealectomised ewes in this study.

In conclusion, the ultrasonographic scanning in pinealectomised ewes was a useful experimental model in the study of melatonin action on the reproductive axis. It allowed observation of both its classical effect on the regulation of seasonal reproduction in short-day breeders and its action on the ovarian functional structures, i.e. the follicle and the corpus luteum. Reported results indicate that melatonin deficiency causes a decrease in plasma antioxidant capacity and alters both follicle and corpus luteum growth dynamics, leading to a decrease in the number of follicular waves/cycle and in the mean area of corpora lutea. It also negatively affected $\mathrm{P}_{4}$ production by luteal cells. These data suggest that melatonin, besides exerting its well-known role in the synchronisation of seasonal reproductive fluctuations, also influences the growth pattern of the follicles and the steroidogenic capacity of the corpus luteum.

\section{Declaration of interest}

The authors declare that there is no conflict of interest that could be perceived as prejudicing the impartiality of the research reported.

\section{Funding}

This work was supported by the Autonomous Region of Sardinia - Special Project Biodiversity. M E Manca and L Torres-Rovira were supported by a MIUR grant. S Succu was supported by a grant from Fondazione Banco di Sardegna.

\section{Acknowledgements}

We would like to thank Prof. Giovanni Bomboi for the support in the hormonal analyses for progesterone determination.

\section{References}

2007 Nutrient Requirements of Small Ruminants: Sheep, Goats, Cervids, and New World Camelids, Washington, DC: The National Academies Press.

Adriaens I, Jacquet P, Cortvrindt R, Janssen K \& Smitz J 2006 Melatonin has dose-dependent effects on folliculogenesis, oocyte maturation capacity and steroidogenesis. Toxicology 228 333-343. (doi:10.1016/j.tox.2006. 09.018)

Arendt J 1998 Melatonin and the pineal gland: influence on mammalian seasonal and circadian physiology. Reviews of Reproduction 3 13-22. (doi:10.1530/ror.0.0030013)

Asa CS, Seal US, Letellier M, Plotka ED \& Peterson EK 1987 Pinealectomy or superior cervical ganglionectomy do not alter reproduction in the wolf (Canis lupus). Biology of Reproduction 37 14-21. (doi:10.1095/ biolreprod37.1.14)

Barros V, Cavalcante A, Macedo T, Barberino R, Lins T, Gouveia B, Menezes V, Queiroz M, Araújo V, Palheta R et al. 2013 Immunolocalization of melatonin and follicle-stimulating hormone receptors in caprine ovaries and their effects during in vitro development of isolated pre-antral follicles. Reproduction in Domestic Animals 48 1025-1033. (doi:10. 1111/rda.12209)

Bartlewski PM, Beard AP, Cook SJ \& Rawlings NC 1998 Ovarian follicular dynamics during anoestrus in ewes. Journal of Reproduction and Fertility 113 275-285. (doi:10.1530/jrf.0.1130275)

Bartlewski PM, Beard AP \& Rawlings NC 2000 An ultrasound-aided study of temporal relationships between the patterns of $\mathrm{LH} / \mathrm{FSH}$ secretion, development of ovulatory-sized antral follicles and formation of corpora lutea in ewes. Theriogenology 54 229-245. (doi:10.1016/ S0093-691X(00)00344-7)

Bartlewski PM, Baby TE \& Giffin JL 2011 Reproductive cycles in sheep. Animal Reproduction Science 124 259-268. (doi:10.1016/j.anireprosci. 2011.02.024)

Behrman HR \& Aten RF 1991 Evidence that hydrogen peroxide blocks hormone-sensitive cholesterol transport into mitochondria of rat luteal cells. Endocrinology 128 2958-2966. (doi:10.1210/endo-128-6-2958)

Behrman HR, Kodaman PH, Preston SL \& Gao S 2001 Oxidative stress and the ovary. Journal of the Society for Gynecologic Investigation $\mathbf{8}$ S40-S42. (doi:10.1016/S1071-5576(00)00106-4)

Benot S, Molinero P, Soutto M, Goberna R \& Guerrero JM 1998 Circadian variations in the rat serum total antioxidant status: correlation with melatonin levels. Journal of Pineal Research 25 1-4. (doi:10.1111/ j.1600-079X.1998.tb00378.x)

Benot S, Goberna R, Reiter RJ, Garcia-Mauriño S, Osuna C \& Guerrero JM 1999 Physiological levels of melatonin contribute to the antioxidant capacity of human serum. Journal of Pineal Research 27 59-64. (doi:10. 1111/j.1600-079X.1999.tb00597.x)

Berlinguer F, Leoni GG, Succu S, Spezzigu A, Madeddu M, Satta V, Bebbere D, Contreras-Solis I, Gonzalez-Bulnes A \& Naitana S 2009 Exogenous melatonin positively influences follicular dynamics, oocyte developmental competence and blastocyst output in a goat model. Journal of Pineal Research 46 383-391. (doi:10.1111/j.1600-079X.2009.00674.x)

Bodis J, Koppan M, Kornya L, Tinneberg HR \& Torok A 2001 Influence of melatonin on basal and gonadotropin-stimulated progesterone and estradiol secretion of cultured human granulosa cells and in the superfused granulosa cell system. Gynecologic and Obstetric Investigation 52 198-202. (doi:10.1159/000052973)

Bronson FH 1995 Seasonal variation in human reproduction: environmental factors. Quarterly Review of Biology 70 141-164. (doi:10.1086/ 418980)

Brzezinski A, Seibel MM, Lynch HJ, Deng MH \& Wurtman RJ 1987 Melatonin in human preovulatory follicular fluid. Journal of Clinical Endocrinology and Metabolism 64 865-867. (doi:10.1210/jcem-64-4865)

Dair EL, Simoes RS, Simoes MJ, Romeu LR, Oliveira-Filho RM, Haidar MA, Baracat EC \& Soares JM Jr 2008 Effects of melatonin on the endometrial morphology and embryo implantation in rats. Fertility and Sterility 89 (Suppl 5) 1299-1305. (doi:10.1016/j.fertnstert.2007.03.050)

Dardente H 2012 Melatonin-dependent timing of seasonal reproduction by the pars tuberalis: pivotal roles for long daylengths and thyroid hormones. Journal of Neuroendocrinology 24 249-266. (doi:10.1111/ j.1365-2826.2011.02250.x) 
Dempsey RJ, Hopkins J, Bittman EL \& Kindt GW 1982 Total pinealectomy by an occipital parasagittal approach in sheep. Surgical Neurology $\mathbf{1 8}$ 377-380. (doi:10.1016/0090-3019(82)90157-4)

Durotoye LA, Webley GE \& Rodway RG 1997 Stimulation of the production of progesterone by the corpus luteum of the ewe by the perfusion of melatonin in vivo and by treatment of granulosa cells with melatonin in vitro. Research in Veterinary Science 62 87-91. (doi:10.1016/S00345288(97)90126-0)

Evans AC, Duffy P, Hynes N \& Boland MP 2000 Waves of follicle development during the estrous cycle in sheep. Theriogenology $\mathbf{5 3}$ 699-715. (doi:10.1016/S0093-691X(99)00268-X)

Fraser S, Cowen P, Franklin M, Franey C \& Arendt J 1983 Direct radioimmunoassay for melatonin in plasma. Clinical Chemistry 29 396-397.

Gatzuli E, Aten RF \& Behrman HR 1991 Inhibition of gonadotropin action and progesterone synthesis by xanthine oxidase in rat luteal cells. Endocrinology 128 2253-2258. (doi:10.1210/endo-128-5-2253)

Gonzalez-Bulnes A, Pallares P \& Vazquez MI 2010 Ultrasonographic imaging in small ruminant reproduction. Reproduction in Domestic Animals 45 9-20. (doi:10.1111/j.1439-0531.2010.01640.x)

Grubaugh W, Sharp DC, Berglund LA, McDowell KJ, Kilmer DM, Peck LS \& Seamans KW 1982 Effects of pinealectomy in Pony mares. Journal of Reproduction and Fertility. Supplement 32 293-295.

Hardeland R, Tan DX \& Reiter RJ 2009 Kynuramines, metabolites of melatonin and other indoles: the resurrection of an almost forgotten class of biogenic amines. Journal of Pineal Research 47 109-126. (doi:10. 1111/j.1600-079X.2009.00701.x)

Herbert J, Stacey PM \& Thorpe DH 1978 Recurrent breeding seasons in pinealectomized or optic-nerve-sectioned ferrets. Journal of Endocrinology 78 389-397. (doi:10.1677/joe.0.0780389)

Jimenez-Krassel F, Folger JK, Ireland JLH, Smith GW, Hou X, Davis JS, Lonergan P, Evans AC \& Ireland JJ 2009 Evidence that high variation in ovarian reserves of healthy young adults has a negative impact on the corpus luteum and endometrium during estrous cycles in cattle. Biology of Reproduction 80 1272-1281. (doi:10.1095/biolreprod.108.075093)

Juengel JL \& Niswender GD 1999 Molecular regulation of luteal progesterone synthesis in domestic ruminants. Journal of Reproduction and Fertility. Supplement 54 193-205.

Kawaguchi S, Sakumoto R \& Okuda K 2013 Induction of the expressions of antioxidant enzymes by luteinizing hormone in the bovine corpus luteum. Journal of Reproduction and Development 59 219-224. (doi:10.1262/jrd.2012-186)

Kennaway DJ, Gilmore TA \& Dunstan EA 1985 Pinealectomy delays puberty in ewe lambs. Journal of Reproduction and Fertility 74 119-125. (doi:10.1530/jrf.0.0740119)

Korkmaz A, Topal T, Tan DX \& Reiter RJ 2009 Role of melatonin in metabolic regulation. Reviews in Endocrine \& Metabolic Disorders 10 261-270. (doi:10.1007/s11154-009-9117-5)

Lewinska A, Wnuk M, Slota E \& Bartosz G 2007 Total anti-oxidant capacity of cell culture media. Clinical and Experimental Pharmacology \& Physiology 34 781-786. (doi:10.1111/j.1440-1681.2007.04637.x)

Lima FB, Machado UF, Bartol I, Seraphim PM, Sumida DH, Moraes SM, Hell NS, Okamoto MM, Saad MJ, Carvalho CR et al. 1998 Pinealectomy causes glucose intolerance and decreases adipose cell responsiveness to insulin in rats. American Journal of Physiology 275 E934-E941.

Lüttgenau J, Beindorff N, Ulbrich SE, Kastelic JP \& Bollwein H 2011 Low plasma progesterone concentrations are accompanied by reduced luteal blood flow and increased size of the dominant follicle in dairy cows. Theriogenology 76 12-22. (doi:10.1016/j.theriogenology.2010.12.025)

Maganhin CC, Fuchs LFP, Simões RS, Oliveira-Filho RM, de Jesus Simões M, Baracat EC \& Soares JM Jr 2013 Effects of melatonin on ovarian follicles. European Journal of Obstetrics, Gynecology, and Reproductive Biology 166 178-184. (doi:10.1016/j.ejogrb.2012.10.006)

Malpaux B, Migaud M, Tricoire H \& Chemineau P 2001 Biology of mammalian photoperiodism and the critical role of the pineal gland and melatonin. Journal of Biological Rhythms 16 336-347. (doi:10.1177/ 074873001129002051)

Messager S, Chatzidaki EE, Ma D, Hendrick AG, Zahn D, Dixon J, Thresher RR, Malinge I, Lomet D, Carlton MB et al. 2005 Kisspeptin directly stimulates gonadotropin-releasing hormone release via $\mathrm{G}$ protein-coupled receptor 54. PNAS 102 1761-1766. (doi:10.1073/ pnas.0409330102)
Murayama T, Kawashima M, Takahashi T, Yasuoka T, Kuwayama T \& Tanaka K 1997 Direct action of melatonin on hen ovarian granulosa cells to lower responsiveness to luteinizing hormone. Proceedings of the Society for Experimental Biology and Medicine 215 386-392. (doi:10. 3181/00379727-215-44148)

Nakamura Y, Tamura H, Takayama H \& Kato H 2003 Increased endogenous level of melatonin in preovulatory human follicles does not directly influence progesterone production. Fertility and Sterility 80 1012-1016. (doi:10.1016/S0015-0282(03)01008-2)

Niles LP, Wang J, Shen L, Lobb DK \& Younglai EV 1999 Melatonin receptor mRNA expression in human granulosa cells. Molecular and Cellular Endocrinology 156 107-110. (doi:10.1016/S0303-7207(99)00135-5)

Ortavant R, Pelletier J, Ravault JP, Thimonier J \& Volland-Nail P 1985 Photoperiod: main proximal and distal factor of the circannual cycle of reproduction in farm mammals. Oxford Reviews of Reproductive Biology 7 305-345.

Poretsky L, Cataldo NA, Rosenwaks Z \& Giudice LC 1999 The insulinrelated ovarian regulatory system in health and disease. Endocrine Reviews 20 535-582. (doi:10.1210/edrv.20.4.0374)

Ravault JP, Arendt J, Tobler I, Chesneau D \& Maulin O 1989 Entrainment of melatonin rhythms in rams by symmetrical light-dark cycles of different period length. Chronobiology International 6 329-339. (doi:10.3109/ 07420528909056939)

Re R, Pellegrini N, Proteggente A, Pannala A, Yang M \& Rice-Evans C 1999 Antioxidant activity applying an improved ABTS radical cation decolorization assay. Free Radical Biology \& Medicine 26 1231-1237. (doi:10.1016/S0891-5849(98)00315-3)

Reiter RJ, De Los Santos R, Dinh DT \& Guerra JC 1980 Melatonin inhibition of reproduction in pinealectomized male Syrian hamsters: effects of various hypothalamic cuts. Anatomical Record 196 153A.

Reiter RJ, Manchester LC \& Tan DX 2005 Melatonin in walnuts: influence on levels of melatonin and total antioxidant capacity of blood. Nutrition 21 920-924. (doi:10.1016/j.nut.2005.02.005)

Reiter RJ, Rosales-Corral SA, Manchester LC \& Tan DX 2013 Peripheral reproductive organ health and melatonin: ready for prime time. International journal of Molecular Sciences 14 7231-7272. (doi:10. 3390/ijms14047231)

Revel F, Ansel L, Klosen P, Saboureau M, Pévet P, Mikkelsen J \& Simonneaux V 2007 Kisspeptin: a key link to seasonal breeding. Reviews in Endocrine \& Metabolic Disorders 8 57-65. (doi:10.1007/s11154-0079031-7)

Robinson JJ, Ashworth CJ, Rooke JA, Mitchell LM \& McEvoy TG 2006 Nutrition and fertility in ruminant livestock. Animal Feed Science and Technology 126 259-276. (doi:10.1016/j.anifeedsci.2005.08.006)

Romeu LR, da Motta EL, Maganhin CC, Oshima CT, Fonseca MC, Barrueco KF, Simões RS, Pellegrino R, Baracat EC \& Soares-Junior JM 2011 Effects of melatonin on histomorphology and on the expression of steroid receptors, VEGF, and PCNA in ovaries of pinealectomized female rats. Fertility and Sterility 95 1379-1384. (doi:10.1016/j.fertnstert.2010.04.042)

Schaeffer HJ \& Sirotkin AV 1997 Melatonin and serotonin regulate the release of insulin-like growth factor-I, oxytocin and progesterone by cultured human granulosa cells. Experimental and Clinical Endocrinology \& Diabetes 105 109-112. (doi:10.1055/s-0029-1211736)

Simko F, Reiter RJ, Pechanova O \& Paulis L 2013 Experimental models of melatonin-deficient hypertension. Frontiers in Bioscience 18 616-625. (doi:10.2741/4125)

Simonneaux V \& Ribelayga C 2003 Generation of the melatonin endocrine message in mammals: a review of the complex regulation of melatonin synthesis by norepinephrine, peptides, and other pineal transmitters. Pharmacological Reviews 55 325-395. (doi:10.1124/pr.55.2.2)

Sirotkin AV 1994 Direct influence of melatonin on steroid, nonapeptide hormones, and cyclic nucleotide secretion by granulosa cells isolated from porcine ovaries. Journal of Pineal Research 17 112-117. (doi:10. 1111/j.1600-079X.1994.tb00121.x)

Smith JT 2012 The role of kisspeptin and gonadotropin inhibitory hormone in the seasonal regulation of reproduction in sheep. Domestic Animal Endocrinology 43 75-84. (doi:10.1016/j.domaniend.2011.11.003)

Soares JM Jr, Masana MI, Ersahin C \& Dubocovich ML 2003a Functional melatonin receptors in rat ovaries at various stages of the estrous cycle. Journal of Pharmacological and Experimental Therapeutics 306 694-702. (doi:10.1124/jpet.103.049916) 
Soares JM Jr, Simões MJ, Oshima CT, Mora OA, De Lima GR \& Baracat EC $2003 b$ Pinealectomy changes rat ovarian interstitial cell morphology and decreases progesterone receptor expression. Gynecological Endocrinology 17 115-123. (doi:10.1080/gye.17.2.115.123)

Taketani T, Tamura H, Takasaki A, Lee L, Kizuka F, Tamura I, Taniguchi K, Maekawa R, Asada H, Shimamura K et al. 2011 Protective role of melatonin in progesterone production by human luteal cells. Journal of Pineal Research 51 207-213. (doi:10.1111/j.1600-079X.2011.00878.x)

Tamura H, Takasaki A, Miwa I, Taniguchi K, Maekawa R, Asada H, Taketani T, Matsuoka A, Yamagata Y, Shimamura K et al. 2008 Oxidative stress impairs oocyte quality and melatonin protects oocytes from free radical damage and improves fertilization rate. Journal of Pineal Research 44 280-287. (doi:10.1111/j.1600-079X.2007.00524.x)

Tamura H, Nakamura Y, Korkmaz A, Manchester LC, Tan DX, Sugino N \& Reiter RJ 2009 Melatonin and the ovary: physiological and pathophysiological implications. Fertility and Sterility 92 328-343. (doi:10.1016/ j.fertnstert.2008.05.016)

Tamura H, Takasaki A, Taketani T, Tanabe M, Kizuka F, Lee L, Tamura I, Maekawa R, Asada H, Yamagata Y et al. 2013 Melatonin as a free radical scavenger in the ovarian follicle. Endocrine Journal 60 1-13. (doi:10.1507/endocrj.Ej12-0263)

Thompson EL, Patterson M, Murphy KG, Smith KL, Dhillo WS, Todd JF, Ghatei MA \& Bloom SR 2004 Central and peripheral administration of kisspeptin-10 stimulates the hypothalamic-pituitary-gonadal axis. Journal of Neuroendocrinology 16 850-858. (doi:10.1111/j.1365-2826. 2004.01240.x)

Tillet Y, Ravault JP, Selve C, Evin G, Castro B \& Dubois MP 1986 Immunohistochemical visualization of serotonin and melatonin in the sheep pineal gland using specific antibodies. Comptes Rendus de I'Académie des Sciences. Série III, Sciences de la Vie 303 77-82.

Vakkuri O, Leppaluoto J \& Vuolteenaho O 1984 Development and validation of a melatonin radioimmunoassay using radioiodinated melatonin as tracer. Acta Endocrinologica 106 152-157.

Vasconcelos JL, Sartori R, Oliveira HN, Guenther JG \& Wiltbank MC 2001 Reduction in size of the ovulatory follicle reduces subsequent luteal size and pregnancy rate. Theriogenology 56 307-314. (doi:10.1016/S0093691X(01)00565-9)

Vázquez MI, Abecia JA, Forcada F \& Casao A 2010 Effects of exogenous melatonin on in vivo embryo viability and oocyte competence of undernourished ewes after weaning during the seasonal anestrus. Theriogenology $\mathbf{7 4}$ 618-626. (doi:10.1016/j.theriogenology.2010.03.007)
Vega M, Carrasco I, Castillo T, Troncoso JL, Videla LA \& Devoto L 1995 Functional luteolysis in response to hydrogen peroxide in human luteal cells. Journal of Endocrinology 147 177-182. (doi:10.1677/joe.0. 1470177)

Wang SJ, Liu WJ, Wu CJ, Ma FH, Ahmad S, Liu BR, Han L, Jiang XP, Zhang SJ \& Yang LG 2012 Melatonin suppresses apoptosis and stimulates progesterone production by bovine granulosa cells via its receptors (MT1 and MT2). Theriogenology 78 1517-1526. (doi:10.1016/j.theriogenology.2012.06.019)

Webley GE \& Luck MR 1986 Melatonin directly stimulates the secretion of progesterone by human and bovine granulosa cells in vitro. Journal of Reproduction and Fertility 78 711-717. (doi:10.1530/jrf. $0.0780711)$

Webley GE, Mehl H \& Willey KP 1985 Validation of a sensitive direct assay for melatonin for investigation of circadian rhythms in different species. Journal of Endocrinology 106 387-394. (doi:10.1677/joe.0.1060387)

Woo MM, Tai CJ, Kang SK, Nathwani PS, Pang SF \& Leung PC 2001 Direct action of melatonin in human granulosa-luteal cells. Journal of Clinical Endocrinology and Metabolism 86 4789-4797. (doi:10.1210/jcem.86. 10.7912)

Woodfill CJ, Wayne NL, Moenter SM \& Karsch FJ 1994 Photoperiodic synchronization of a circannual reproductive rhythm in sheep: identification of season-specific time cues. Biology of Reproduction $\mathbf{5 0}$ 965-976. (doi:10.1095/biolreprod50.4.965)

Yie SM, Niles LP \& Younglai EV 1995 Melatonin receptors on human granulosa cell membranes. Journal of Clinical Endocrinology and Metabolism 80 1747-1749.

Zarazaga LA, Celi I, Guzmán JL \& Malpaux B 2010 Melatonin concentrations in the two jugular veins, and relationship with the seasonal reproductive activity in goats. Theriogenology 74 221-228. (doi:10.1016/j.theriogenology.2010.02.005)

Zucker I 1985 Pineal gland influences period of circannual rhythms of ground squirrels. American Journal of Physiology 249 R111-R115.

Received 27 August 2013

First decision 9 October 2013

Revised manuscript received 13 February 2014

Accepted 25 February 2014 